\title{
The Siberian Studies Manifesto
}

\author{
ALEXANDER D. KING
}

\section{Our Interdisciplinary Journal for the Region}

$7 \neg$ his issue marks the re-launch of our journal with Berghahn after a 1 year's hiatus in publishing. I would like to thank Vivian Berghahn and her team in the journals division for all their efforts in working with us to continue the journal and improve upon the excellent base established by Alan Wood and Cathryn Brennan. As editor, I coordinate the work of the associate editors, who put in many of the hours necessary to prepare high-quality manuscripts for publication. In volume four, we published short editorial notes that were collectively signed. This manifesto marks the introduction of a new genre to the journal, a substantive editorial intended to provoke discussion on a particular topic. It is authored by a single person, but distributed for comment to the other editors, and although not peer-reviewed, it has at least received some peer discussion before going to press. We will take turns stepping onto the soapbox, and we invite our readers to contribute to discussions, as well. The topic at hand is very broad: the place of Siberian studies in the humanities and sciences generally.

First, a note about the term 'interdisciplinary' in our subtitle and its role in Siberian studies. The term has been reduced to a buzzword of little import in much usage, but we take the idea behind it very seriously, even more so as the editorial committee acknowledges that we are all (and only) anthropologists. I have participated in several events heralded as interdisciplinary, and I know firsthand that fruitful discussions are possible, but they are hard work. Interdisciplinarity is often accomplished only so far as crossing of disciplinary boundaries within an otherwise comfortable discursive framework-philosophers talking to historians or literary critics, anthropologists talking to sociologists or political scientists, biologists talking to ecologists or geologists. We envision something broader in the pages of this journal. Sibirica is intended 
as a truly interdisciplinary forum where scholars representing a wide variety of disciplines from around the world can present findings and discuss topics of relevance to human activities in the region or directly relevant to Siberian studies. This latter qualification leaves the door open to articles focused on places like Alaska, Mongolia, Karelia, or anywhere else where direct contact or even just direct comparison with Siberians is obvious and useful in the advancement of Siberian studies. We are not interested in drawing sharp boundaries that will hinder discussion, but in pursuing lines of inquiry that will advance our understanding. Indeed, many people have told me that places like Kamchatka and Chukotka are not properly part of Siberia, but are situated in the Russian Far East. On the other hand, following Bogoras (1902: 579), I have published a translation and discussion of Koryak narratives in a collection of oral literature from Native North Americans (King 2004). Thus, while it may be impossible to be in two places at once, it can be very productive for a place to be in more than one category.

Most importantly, we want to foster a scholarly discussion among people with the most varied backgrounds and points of view. Thus, we invite submissions from politicians and activists, as well as from scholars ranging from the humanities to the natural sciences. We ask only that the people of Siberia be the central focus of the article. Thus, I can easily imagine publishing excellent contributions from zoologists, soil biologists, and geologists. While a technical discussion of plate tectonics in Kamchatka may not be appropriate for Sibirica, a survey of the state of volcanology in the Russian Far East certainly is.

Historians and literary critics are also encouraged to publish in Sibirica, and because we embrace the full range of scholarship, we have instituted a dual citation system. This may seem petty at first glance, but I know many anthropologists who chafe at being forced to write using endnote citation style instead of the author-date format more familiar to them. The value of endnotes for historians, however, was driven home to me recently as I was reading an excellent biography of the anthropologist and linguist Edward Sapir. The author is an anthropological linguist of considerable skill and repute, but I found her use of standard author-date citations for archival sources, correspondences, and other historical documents to be cumbersome and, in one or two instances, even interfered with my understanding of the text.

The second point I want to emphasize in this call for papers is a description of the kind of material Sibirica is most interested in publishing. I have already invited readers to contribute to discussions in the editorial forum. I also want to encourage submissions of a very differ- 
ent kind of writing, something we are calling 'research reports'. We envision brief pieces (2,000-6,000 words) that are not full journal articles. A research report need not cite secondary sources, let alone review the relevant literature. It could be the publication of a report sent to a grant agency, summarizing recent work accomplished. It could provide a summary description of a specific archive, be a translation of key documents, or describe archival resources on a certain topic. Ethnographers may wish to summarize a recent trip to the field. Archeologists can tell us the main discoveries from their last field season. Linguists could report on the number and quality of speakers they worked with during their latest trip to document a little-spoken language. Research reports should have a point to make, not just be a laundry list of 'facts', but they need not advance the 'state of discipline' beyond providing more information on a specific topic. In this way, Sibirica will keep readers apprised of the most current work being undertaken in the region.

Most importantly, whether the manuscript is intended as a research report or a full article, the text needs to be comprehensible to a wide audience outside of the author's disciplinary specialty. Thus, while linguistic descriptions of a language are welcome, authors who dwell on a technical discussion of laryngialization in language $X$ and its implications for theoretical phonetics will be asked to rewrite that section or cut it altogether. I do not mean to discourage a high level of scholarly debate, but the editors of Sibirica would like authors to avoid disciplinary jargon (which may be most helpful when communicating within a discipline) and to communicate with a broad spectrum of Siberianists.

Sibirica is a regional studies journal, but it is not parochial in thought or expression. It has played and will continue to play the preeminent role in disseminating scholarly contributions to our knowledge of Siberia past and present. In my own work as an anthropologist in Siberia, I have found other regional journals, such as Études/Inuit/Studies and Oceania, just to name two, extremely valuable for understanding what is unique and what is not unique about Siberia. I hope that people studying other parts of the world will likewise find Sibirica useful to their work.

\section{A Peripheral Region at the Core of Key Debates}

To come to the core of my manifesto, I believe that Siberia lies at the heart of some of the great puzzles for understanding what it is to be a human being. For example, shamanism is seen by some as the original 
religion of pre-agricultural humans (Vitebsky 2005: 12). For others, shamanism lies at the core of the New Age, and is thus the key to understanding the future of humanity. While such claims may be a bit extreme for many ethnographers and historians working in Siberia, we can contribute positively to the discussion through careful description and analysis of what Siberians are up to in this regard. I find it ironic that an anthropologist of Native North Americans, seeking to dispel misconceptions about the homogeneity of practices by different people around the world often termed 'shamanic', produced a book subtitled Exploration in Critical Thinking which homogenizes the variety of human and non-human (i.e., spirits or animals) relations among different Siberian cultures (Kehoe 2000). ${ }^{1}$

The debates surrounding the peopling of the Americas are also inextricably connected to Siberia and the study of Siberian peoples. The Jesup North Pacific Expedition by the American Museum of Natural History was the first big project to examine the question in detail. Through this project, Siberian studies not only consolidated the professional reputation of Franz Boas and launched the careers of several key American anthropologists; it also launched the professional career of Vladimir Bogoraz and shaped the early years of professional Russian and Soviet anthropology. Nowadays, the methods used to answer the question of the peopling of the Americas are very different, and they are at the forefront of key research in human genetic diversity. I expect Sibirica will play an important role in advancing our understanding of the peopling of the Americas and many of the details of human genetics.

Siberia is a key region for the world's energy needs, and understanding oil and gas operations in the region will take much more than the usual Kremlinology (e.g., recent media discussion of Gazprom's relations with Austria and Germany), as the very next issue of Sibirica, a special issue on oil and gas industries in Siberia, will demonstrate. In a broader context, extractive industries (such as gold, diamond, and other kinds of mining, as well as oil and gas extraction) are not at all new in Siberia. The Siberian fur trade was called 'soft gold' for good reason, but gold itself has long been extracted from Siberia, specifically in the Altai region. These industries were a cornerstone of the Soviet economy, and as agriculture and manufacturing collapsed in the postSoviet debacle, these industries are the mainstay of the new Russian economy and play an increasingly important role in Europe and global economic and political affairs. The very next issue of Sibirica (guest edited by Emma Wilson and Florian Stammler) will focus on problems related to the operations of oil and gas industries in the region. While 
critical to the region, they are not just regional issues, as oil and energy industries impact the daily lives of everyone on this planet in many ways.

\section{Siberia at the Center of a Theory of Empires}

Above I outlined just a few examples of what I believe are key debates from the close of the last century and in the beginning of this one. Now I turn to a more detailed discussion on the place of Siberia in understanding empires and colonialism generally. Whatever Siberia's peripheral status, every student of Russian history knows that the region has been the core of Russia's imperial development. I believe that the study of Siberia is important beyond investigations of the Russian Empire. The role of empires and colonialism in the development and future of the contemporary social, political, and economic lives of people around the world is an enduring concern. Siberia has played a key role in some of the greatest empires in history-Russian and Mongolian, as well as others-the history and archeology of which will aid our understanding not only of humanity's past, but of our present and future as well. Looking at general discussions of post-socialism, I find a consensus that recurrent patterns in actually existing socialism were due in large part to the imperial presence of the Soviet Union in Eurasia (Bridger and Pine 1998; Burawoy and Verdery 1999; Hann 2002). Much of post-socialism, then, at least implicitly defines its subject as the investigation of the legacy of the Soviet empire. Particularly, if we examine the lives of indigenous peoples and their histories of encounters with empires, some interesting patterns emerge. The category of indigeneity is itself deeply problematic and timely. Siberianists have much to contribute on this debate, which is too often confined to areas such as the Americas and Australia.

Post-colonial studies of Western imperial legacies in Asia, Africa, and South America provide some useful lines of research and theorizing in post-socialist areas, as Verdery (2002) suggests, but Siberian studies also have much to contribute to theories of empire and the post-colony. Colonialism and post-colonialism highlight oppositional categories of people: colonizers and colonized. I prefer empires and imperialism as analytic categories because they ask slightly different questions. I am interested in empires as particular social systems of power and value existing in specific historical moments. My questions focus on the similarities and differences among various imperial representa- 
tions of peoples. The Soviet empire was different from those of Great Britain and France, to be sure, particularly with respect to the priority of territorial security of the core (Russia) over priorities of capital accumulation or even material wealth. However, these differences, or the difference between a contiguous land empire and one with overseas colonies, should not distract us from some striking similarities. Empires in the nineteenth and twentieth centuries are surprisingly similar with respect to representations of the colonized and social and political policies regarding small (often called 'indigenous') groups on the peripheries. The role of Koryak culture in the Soviet Union and the experience of Koryak people in Kamchatka under Soviet and post-Soviet Russia is analogous to similarly small and peripheral groups in French, British, Spanish, and even American empires. There are key differences, of course, and these differences tell us as much about French, British, and Spanish empires as they tell us about Russian and Soviet empires.

Rome is the prototype of an empire in Western thought and gave us the term, but we have many other examples, such as the Aztec and Incan empires. Modern China is as much an empire as ancient China or Mongolia was. One may want to argue that the modern state of India is an empire, or as Piers Vitebsky has quipped, "an empire masquerading as a nation-state" (personal communication); the same can be said for the Russian Federation. The United States is an empire, although one may prefer to think of Indian reservations as "internal colonies" (Hechter 1975), and American hegemony reaches far beyond its direct political dominion. Finally, we should keep in mind that Exxon-Mobile, Coca-Cola, and Sony may be usefully analyzed as empires, especially with respect to their activities in places like Sakhalin Island, Nigeria, and Alaska's North Slope. Thus, I ultimately do not want to define empires as states, but as very large social systems of power and value extraction (cf. Hardt and Negri [2000], who see this as a fundamental break with past empires). Imperial cores can be defined as the social or geographical areas benefiting the most from the extraction of value, which occurs in peripheral zones. Although typically discussed as a periphery, Siberia lies at the core of the Russian (and Soviet) empire, and, hence, understanding Siberians lies at the core of understanding past and contemporary imperial ideologies and practices. For example, imperial worldviews seem to populate the globe with ethnic groups. The main elements used to distinguish one ethnic group from another have been language and ethnonym, followed in importance by differences in economic practices and material culture. The Tsarist inventory of peoples of the empire was elaborated into a baroque typology of eth- 
nicity among Soviet anthropologists (Anderson 2000; Balzer 1999; Hirsch 2005). Oscar Salemink's description of French colonial rule in highland Vietnam reveals a logic of typological ethnic groups in French administration similar to the Soviet hierarchy of "peoples" (Salemink 1991: 244-247, see also Salemink 2003). At first the French used language groups to define administrative territories, which led to the establishment of 'groups' with 'ethnic identities'. As well, much of the Bureau of American Ethnology program for identifying and classifying American Indian languages was connected to a colonial system of administering tribes within the Bureau of Indian Affairs (BIA) bureaucracy (Feit 1991: 113).

Indigenous Siberians' experiences in the internat residential school system were similar in many ways to those of Africans in colonial schools in Kenya, as well as those of Native Americans (Bartels and Bartels 1995, Bloch 2004, Thiong'o 1994). Thiong'o describes how schools were more important for colonization than guns and physical oppression. As a small child, his native language was used for all spheres of life, but at the colonial school, "the language of my education was no longer the language of my culture" (Thiong'o 1994: 438). As in Kamchatka, children in Kenya were physically punished and shamed for using their native language, and they were rewarded for using the colonial language (King 2000: 131). Salish Indians were attending similar schools in the 1920s and 1930s in Washington State. Dell Hymes (personal communication) has also heard similar school experiences by Indians in Oregon. More extensive comparison of northern imperial schooling and of recent policies for language revival efforts may reveal more similarities than differences between Soviet imperial practices and so-called capitalist imperialism. At least one collection of essays on education and empires (Myrsiades and McGuire 1995) provides several other examples on how representations in the classroom serve to reproduce imperial categories, but which can be sometimes contested. I fervently hope that Sibirica will contribute to these discussions. One great difference between Soviet and other empires is the ideological commitment to total incorporation of all peoples, and the high degree of enfranchisement of indigenous Siberians into the Soviet system (discussed in Bloch 2004; Gray 2005).

In other ways, the colonial experience in Chukotka and other parts of Siberia is analogous to French Polynesia in the late twentieth century. Kahn $(2000,2003)$ argues that the symbolic functions of Tahiti and French Polynesia as signs of global empire far outweigh the possible military or economic functions for the French state. The Soviet Union 
continued and intensified practices of domination and presence in the Russian Empire through 'development' of such regions as Chukotka, which also had symbolic importance far greater than economic or military needs (Gray 2005: 93ff.). The Bilibino nuclear power station in Chukotka was built there, north of the Arctic Circle, not because it was an economically beneficial project for the core, but because it could be done. The Soviets glorified such achievements as indications of the Soviet way of life, as the pinnacle of human historical evolution and 'cultural development'. The attention and resources committed for developing northeast Asia are due in no small part to the legacy of Chukotka as a region "not completely subdued" by the center as late as the beginning of the twentieth century, a region where the indigenous inhabitants were more likely to have acquired English as a second language rather than Russian (Forsyth 1992: 150; Kolarz 1954: 89-91). Robert Wishart (2004: 67-69) has noted that the Hudson Bay Company was willing to take huge losses in Northwest Canada in the short term as part of an imperial strategy to secure a monopoly in trade and support territorial claims of the British Empire. Also, the English ability of early twentieth century Chukchi men is connected to a nascent American commercial imperialism operating in the Pacific.

Some may object that one problem with using post-colonial theory to understand the situation of indigenous Siberians is that Siberia is still a colony of Russia. There are certainly indigenous leaders in Siberia who argue that native people continue to suffer from Russian colonization. Some of my Russian colleagues have explained to me that Western anthropologists are wrong when they write about Siberia as a colony. They make the distinction between a foreign territory held as a colony by an imperial power and lands which happen to be distant from the center, but are incorporated into the same polity as the center. Siberia is not a colony like India or South America was because it has been fully integrated, legally and politically, into the Russian state. One can counter with Hechter's model of the internal colony, which can be identified through other structural features of subordination in economic, administrative, and social spheres. But even granting the point that Siberia is no longer the colony it was in the 18th century, then logically, it is a post-colony. If we discard the terms colony and post-colonialism in favor of empires and imperialism, the rug is pulled out from underneath such an argument, since we don't have to define empires in terms of colonies. Colonies certainly are an important feature of empires, and I believe that even non-state empires like Sony and British Petroleum have colonies, although not in our usual sense. Another advantage to 
framing analysis in terms of empires and not colonies is that we don't need to resort to arguments such as internal colonialism, which I find a bit tortuous. Past imperial policies certainly oppressed plenty of people living in metropoles such as London and Moscow, although perhaps differently than they oppressed people in the peripheral areas like the Yukon and Kamchatka. Another reason for my lack of enthusiasm for post-colonialism as a frame of reference is that it has developed through an analysis of British and other capitalist overseas empires. My arguments for the merging of post-socialism and post-colonialism do not favor a folding of the former into the latter. The differences between Soviet imperial legacies and British imperial legacies, which I have glossed over here, cannot all be accounted for by post-colonial theory. I would like to entertain the prospect of a Unified Theory of Empires, and I see Siberian studies playing a central role in this project.

Thus we find Siberia, often held up as the epitome of peripheral areas, at the very center of many of the debates defining the zeitgeist of the twenty-first century, as well as central to understanding key areas of humanity's past. Shamanism, human genetic diversity, oil and mining industries, indigenous peoples, colonialism and empires-these are all specific topics with special relevance to Siberian studies, but they only scratch the surface of the variety of topics covered in the first four volumes of Sibirica. Although my own work focuses on indigenous Siberians, and much of this manifesto discusses indigenous Siberians, the journal Sibirica is not limited to any one segment of Siberia. The first issue under our collective editorship was a special issue on youth cultures, edited by Otto Habeck, and many of the articles in that issue examined urban spaces and collectively described a wide range of social groups.

Regional studies lost much credibility, especially regions connected to Slavic studies, after the end of the cold war. However, localities remain as important as ever in an increasingly globalized world. I think the least contentious claim for readers of this journal is that Siberia is a fascinating region. I thus foresee much fascinating reading within the pages of Sibirica.

Alexander D. King is lecturer of anthropology at the University of Aberdeen and Editor of Sibirica. Previously he was a researcher at the Max Planck Institute for Social Anthropology in Halle, Germany and assistant professor at Chico State University, California. He is co-author (with Deema Kaneff) of "Owning Culture" in Focaal 44 
(2004) and author of "Without Deer, there is No Culture, Nothing" in Anthropology and Humanism 27 (2002). He is currently completing a monograph on indigenous language and culture in Kamchatka.

\section{Notes}

1. The greatest irony of Kehoe's work for me is her use of Koryaks as the poster boys (literally, reproducing several plates by Jochelson of Koryak shamans) for Siberian shamans when most of the Koryaks I have talked to detest that word as a label for powerful individuals!

\section{References}

Anderson, David G. 2000. Identity and Ecology in Arctic Siberia: The Number One Reindeer Brigade. Oxford: Oxford University Press.

Balzer, Marjorie Mandelstam. 1999. The Tenacity of Ethnicity: A Siberian Saga in Global Perspective. Princeton: Princeton University Press.

Bartels, Dennis A. and Alice L. Bartels. 1995. When the North Was Red: Aboriginal Education in Soviet Siberia. Montreal: McGill-Queen's University Press.

Bloch, Alexia. 2004. Red Ties and Residential Schools: Indigenous Siberians in a PostSoviet State. Philadelphia: University of Pennsylvania Press.

Bogoras, Waldemar (Bogoraz, Vladimir G.). 1902. "The Folklore of Northeastern Asia, as Compared with that of Northwestern America." American Anthropologist. 4:577-683.

Bridger, Susan, and Frances Pine, eds. 1998. Surviving Post-socialism: Local Strategies and Regional Responses in Eastern Europe and the Former Soviet Union. New York: Routledge.

Burawoy, Michael, and Katherine Verdery. 1999. Uncertain transition: Ethnographies of Change in the Postsocialist World. Lanham, MD: Rowman \& Littlefield.

Feit, Harvey A. 1991. "The Construction of Algonquian Hunting Territories: Private Property as Moral Lesson, Policy Advocacy, and Ethnographic Error." Pp.109-134 in George W. Stocking, Jr., ed., in Colonial Situations: Essays on the Contextualization of Ethnographic Knowledge. History of Anthropology 7. Madison: University of Wisconsin Press.

Forsyth, James. 1992. A History of the Peoples of Siberia: Russia's North Asian Colony 1581-1990. Cambridge: Cambridge University Press.

Gray, Patty A. 2005. The Predicament of Chukotka's Indigenous Movement: PostSoviet Activism in the Russian Far North. Cambridge: Cambridge University Press.

Hann, C. M. 2002. Postsocialism: Ideals, Ideologies and Practices in Eurasia. London: Routledge.

Hardt, Michael, and Antonio Negri. 2000. Empire. Cambridge, MA: Harvard University Press. 
Hechter, Michael. 1975. Internal Colonialism: The Celtic Fringe in British National Development, 1536-1966. Berkeley: University of California Press.

Hirsch, Francine. 2005. Empire of Nations: Ethnographic Knowledge and the Making of the Soviet Union. Ithaca, NY: Cornell University Press.

Kahn, Miriam. 2000. "Tahiti Intertwined: Ancestral Land, Tourist Postcard, and Nuclear Test Site." American Anthropologist. 102 (1): 7-26.

—. 2003. "Tahiti: The Ripples of a Myth on the Shores of the Imagination." History and Anthropology. 14: 307-26.

Kehoe, Alice Beck. 2000. Shamans and Religion: An Anthropological Exploration in Critical Thinking. Prospect Heights, Ill.: Waveland Press.

King, Alexander D. 2000. "Trying to be Koryak: Soviet Constructions of Indigeneity in Kamchatka, Russia." PhD diss., University of Virginia.

—. 2004. "Raven Tales from Kamchatka." Pp. 3-24 in Brian Swann, ed., Voices from the Four Directions. Lincoln: University of Nebraska Press.

Kolarz, Walter. 1954. The Peoples of the Soviet Far East. New York: Praeger.

Myrsiades, Kostas, and Jerry McGuire. 1995. Order and Partialities: Theory, Pedagogy, and the "Postcolonial". Albany: State University of New York Press.

Salemink, Oscar. 1991. "Mois and Maquis: The Invention and Appropriation of Vietnam's Montagnards from Sabatier to the CIA." Pp. 243-284 in George W. Stocking, Jr., ed., Colonial Situations: Essays on the Contextualization of Ethnographic Knowledge. History of Anthropology 7. Madison: University of Wisconsin Press.

— 2003 The Ethnogrtaphy of Vietnam's Central Highlanders: A historical contextualization, 1850-1900. London: RoutledgeCurzon.

Thiong'o, Ngugi wa. 1994. The Language of African Literature. Pp. 435-456 Patrick Williams and Laura Chrisman, eds., Colonial discourse and PostColonial Theory. New York: Columbia University Press.

Verdery, Katherine. 2002. "Whither Postsocialism?" Pp. 15-22 in Chris M. Hann, ed., Post-Socialism: Ideals, Ideologies and Practices in Eurasia. London: Routledge.

Vitebsky, Piers. 2005. The Reindeer People: Living with Animals and Spirits in Siberia. Boston: Houghton Mifflin Company.

Wishart, Robert. 2004. "Living on the Land: Teetlit Gwich'in Perspectives on Continuities." PhD diss., University of Alberta. 